CATALAN REVIEW

Catalan Review

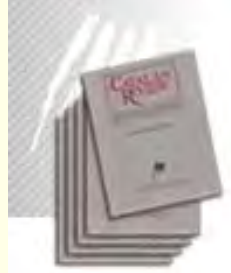

You are accessing the Digital Archive of the Catalan Review Journal.

By accessing and/or using this Digital Archive, you accept and agree to abide by the Terms and Conditions of Use available at http://www.nacs-

catalanstudies.org/catalan_review.html

Catalan Review is the premier international scholarly journal devoted to all aspects of Catalan culture. By Catalan culture is understood all manifestations of intellectual and artistic life produced in the Catalan language or in the geographical areas where Catalan is spoken. Catalan Review has been in publication since 1986 .
NORTH

AMERICAN

CATALAN

SOCIETY
Esteu accedint a l'Arxiu Digital del Catalan Review

A l' accedir i / o utilitzar aquest Arxiu Digital, vostè accepta i es compromet a complir els termes i condicions d'ús disponibles a http://www.nacs-

catalanstudies.org/catalan_review.html

Catalan Review és la primera revista internacional dedicada a tots els aspectes de la cultura catalana. Per la cultura catalana s'entén totes les manifestacions de la vida intel lectual i artística produïda en llengua catalana o en les zones geogràfiques on es parla català. Catalan Review es publica des de 1986.

\title{
The feminism (anti-feminism) according to Montserrat Roig Isolina Ballesteros
}

Catalan Review, Vol. VII, number 2 (1993), p. 117-128 


\section{THE FEMINISM (ANTI-FEMINISM) ACCORDING TO MONTSERRAT ROIG}

\section{ISOLINA BALLESTEROS}

"Una coneguda feminista espanyola ens va acusar, a Carme Riera i a mi, de ser d'un "feminisme tebi" perquè a les nostres novel-les mai no havíem descrit com tots els marits violen les seves dones" (76). So Montserrat Roig writes in her last (and posthumous) collection of essays, Digues que m'estimes encara que sigui mentida, published in 1992. A couple of years earlier, in an interview, Roig had already mentioned this "well known feminist['s] accusation»: "Lidia [Falcón] ha dicho que mis novelas son antifeministas porque yo no hablo de las mujeres apaleadas por sus maridos” (Nichols, 158). Lidia Falcón, founder of the Revista del Partido Feminista de España, considered L'hora violeta a treason to feminism and criticized its author harshly for questioning and ridiculing in it the strategy of hard line feminists to codify the world in "hombre-malo, mujer-víctima" (I9). In the same article Falcón discredits also the love discourse of the feminine narrative's characters. She is specifically speaking about the feminine characters of Roig's novels, but also about those of Carme Riera, Rosa Montero as well as Pilar Miró's film, Gary Cooper que estás en los cielos. These characters spend their lives looking for passionate and romantic love, and this search, in Falcón's opinion, keeps them in the same position of fragility, insecurity and dependency that have always been assigned to women throughout history, leading them irremissibly to play the eternal role of victims deceived by men (Falcón, 23). Nor does Falcón like either that Roig's characters belong to a well-to-do social class because, according tô her they are not representative of the "real world" problems. This is how she describes them:

Las heroínas de nuestra narrativa femenina no tienen problemas económicos, casi nunca profesionales, o éstos están mediatizados y a veces abortados por sus 
preocupaciones sentimentales, no poseen maridos gruñones, golpeadores, borrachos. nińos subnormales o molestos, suegras, cuñadas, cuñados, hermanos, padres y madres, ninguno de los personajes que constituyen el variopinto y asfixiante entorno familiar. Las protagonistas de la llamada novelística feminista ¿se lo creerán?, son inmaduras, débiles, vacilantes, enamoradas del amor, engañadas por mozos algo egoístas, pero fuertes, profesionales o militantes políticos, decididos, arriesgados, mentirosos o veraces, pero de personalidades seguras, que ponen de relieve la insegura personalidad femenina que lucha por encontrar su huequecito en el lugar donde se dice que perdió su primera costilla Adán. (23)

According to this, Falcón wonders:

...si las escritoras feministas escriben y describen así a las mujeres y a los hombres, si en su universo no existen prostitutas, ni entregas sexuales por dinero o por ascensos profesionales, si sus hombres ni violan, ni agreden ni explotan a sus mujeres, si las mujeres son temerosas, vacilantes, débiles y necesitan siempre un soporte masculino para poder salir adelante en la profesión, en la vida, en fin ¿qué podrán decir y hacer los hombres? (23)

Lidia Falcón is not the only one. In their 1987 article, Romero, Alberdi, Martínez and Zauner agree with her that the novelists of the 70's, Roig included, do not go deeply into the themes they write about; they still depict the feminine world as dependent, isolated and enclosed in domestic spaces; they become choniclers of their own reality, creating thus a self-complacent literature, full of lament and nostalgia, passivity and helplessness; they are prisoners of their inability to find solutions to their problems inside themselves (256).

It seems problematic to classify every female character in Roig's novels according to the above characterization, as well as limiting to talk in terms of feminist or anti-feminist novels or novelists. As Catherine Bellver has shown in her studies of Roig's novels, there is no unitary position towards feminism in Roig's novels. On the contrary, they present a wide range of positions: compromised, divergent and even contradictory in the case of Norma and Natalia (L'hora violeta);

'See the articles, "Montserrat Roig and the Penelope Syndrome", and "Montserrat Roig: A Feminine Perspective and a Journalistic Slant». 
lacking ideological support, but not less effective, are the initiatives of Agnès (also in L'hora violeta) and Mari-Cruz in Lòpera quotidiana.

Montserrat Roig declared in her last collection of essays that today the woman writer does not have to apologize or excuse herself for her writing (Digues que m'estimes, 67). However, and ironically, she was forced to clarify on more than one ocasion, and as a response to the mentioned critics, her own position towards feminism. Roig rebels explicitly against the reductionism of woman to an ideological construction and against the homogenizing and dogmatic tendency of certain feminist critics who look for the «utopia de la feminitat", «'heroïna positiva", "un model a seguir", "una nova aplicació del realisme socialista, ara realisme feministas (76) in each text. Roig complains that: "Les crítiques feministes corren el perill d'inventar-se el prototipus d'una escriptora model, encotillada, inexistent. I l'escriptora, que practica un art individualista, s'hi rebel.law (70). The fates of her female characters seem to be representative of her personal conception of the role of women in our society and of what they can or cannot accomplish today. Feminist criticism wants to encourage the woman writer by proclaiming the self-consciousness that "ens aparta del lament $\mathrm{i}$ ens duu a l'autonomia" (70). Nonetheless, to Roig, some feminists do not seem to realize that a feminine text is also autonomous and feminine when it is intertwined with «les boires del seu ressentiment, ... la sospita dels seus fracassos, ... l'angoixa davant la gran por ..." (70). The absolute liberation of female characters, required by hard line feminists, seems irreconcilable with heterosexual love, which has always assigned them the traditional role of the resigned Penelope awaiting the return of Ulysses. Catherine Bellver argues that Norma and Natalia, by reading their predecessor's text, are challenging the concept of the Penelope syndrome:

Because texts by women have been submerged, ignored, and misinterprered, Norma and Natalia's reading of Judith's diary and their re-reading of the Penelope myth becomes a comprehensive act of discovery, consciousness, and reevaluation of woman as writer, reader, and actor. Their response transcends mere readjustment to include re-creation, if not actual realization of a female 
reality, for they establish, within patriarchal, androcentric culture, the existence of a rich female social and cultural context. (1987:119)

Through the realization of a feminine identity, they discover also that sexual liberation and the rejection of traditional roles have not solved the dilemma of love. As Bellver puts it: «They... sense that feminism has neither reconciled women's need for autonomy with their desire for love nor taken into account the possibility of intense and total love between a woman and a man" (1987:119). In spite of their ideologically liberated attitudes, they share with the mythic Penelope more than they would like. Bellver points out the fact that ironically "those who defy the Penelope syndrome - the youngest Ramona and Jordi's wife- do so without the ideological base of feminist thinking" (1987:120). She suggests that "Roig may be indicating the failure of feminism to resolve the dilemma of the psychic necessities of women as well as suggesting that the successful challenge of social myths is effected through personal resolve rather than intellectual theory" (1987:I20).

Did the question marks used for the title of her collection of essays ¿Tiempo de mujer? (1980) indicate that "woman's time" had not yet arrived? Does the title of her last collection of essays (Digues que m'estimes encara que sigui mentida), published twelve years later, suggest that it still has not arrived or that the crucial dilemma of love and interpersonal relationships still has not changed?

Bellver's conclusions allow us to make a great number of connections between Roig's female characters and those of some of her contemporaries in order to see if we can answer these questions. These connections were already made by feminist critics, as we have just seen, in a more or less positive or dogmatic fashion. Roig is reacting against dogmatism when she declares her position towards feminism contrary to any kind of ideologic reductionism. We can detect the same intention in the works of many of her contemporaries. A very different type of connection will help me make this point. The title of Roig's collection of essays Digues que miestimes encara que sigui mentida, which refers intertextually to the film 
Johnny Guitar, transports us to another text about female characters, which also uses the American film as intertextual reference. In Pedro Almodóvar's Mujeres al borde de un ataque de nervios, the protagonists, dubbing the dialogues of the American film's characters, repeat and duplicate their counterparts tragedy." Almodóvar's "women" as well as many female characters in Roig's novels have awaited their beloved men before and after being abandoned by them. All these women question the usefulness of a militant feminism that does not help them solve the problems of their emotional life. They also realize the distance that exists between the theory and the practice of their commitment, between the public and the private realm of their life. Norma aknowledges in L'hora violeta that: «Ella, que creia viure una vida diferent d'altres dones... I li havia passat el mateix que a la gran majoria..." (r70); she says to Natalia: "El meu marit m'ha deixat per la seva amant, i el meu amant em deixa per la seva dona" (17I); and in the meantime her lover's wife, Agnès, uodiava les militants feministes perquè intuïa que una d'elles li havia pres l'homes" (209). In Mujeres al borde de un ataque de nervios, Ivan had first left his wife for Pepa and then Pepa for his wife's feminist lawyer. The rejection of this publicly but not privately committed feminism is depicted and ridiculed in the film through the character of this feminist lawyer to whom, in Roig's character's words, "el feminisme no li havia donat les dades" (I82) to reconcile passionate love and solidarity with the women she claims to be defending from men like Iván. Natalia has also discovered that "no li servien de res... tots els mitings i llibres sobre feminismen (225). In spite of her discovery she will still have to wait, "esperar davant del telèfon, mirant de fit a fit

$=$ See the article of Marvin D'Lugo, «Heterogeneity and Spanish Cinema of the Eighties": "The [dubbing sequence in which Pepa and Iván are engaged at various points] ... is a clip from Nicholas Ray's Johnny Guitar in which Sterling Hayden delivers his famous "rell me lies" speech to Joan Crawford. Self-consciously cueing the audience to self-deluding male's desires for dominance and the understanding of those desires by the emotionally liberated female, this scene eventually reveals itself to be the interior duplication of Pepa's gradual liberation from Iván's phallocentrism" (65). 
l'aparell, com si tingués vida pròpia... O potser esperaria el truc impossible de la porta.... (225-26), in the very same way Vienna (in an American Western saloon), Agnès (in her apartment at the Barcelona's Ensanche) and Pepa (in her postmodern Madrid apartment) do. While Norma, an open feminist, confronts this reality through writing, Pepa throws the telephone out of the window and burns the bed used to share with Iván in a symbolic purgation and liberation act; and Agnès, in the last pages of L'hora violeta, decides to leave for good the role of the abandoned woman, refusing Jordi's request to resume their relationship:

només va dir, no... I no li deia que no pels gemecs de la mare que li recomanaven paciència, ni pels discursos [feministes] de la Norma, ni tampoc pel que li havia dit el capità Haddock, allò de què no ens resignem a perdre el que estimem, o potser deia que no per tot plegat. (231-32)

However due to some of the doubts, indecisions, and open critiques against dogmatic feminism that Roig has placed in her female characters, especially in L'hora violeta, she has been criticized as anti-feminist. Roig has clarified her position in more than one form. In an interview with Graldine C. Nichols, she comments on L'hora violeta:

No quise hacer un panfleto feminista, pero sí quise hacer una novela que explicara la crisis de la mujer que quiere ser fuerte y no lo es, que quiere vivir como un ser independiente cuando su subsconciente todavía está dominado...; no he querido hacer personajes positivos de las mujeres, ni personajes negativos de los hombres. Sólo he querido explicar esto, lo que nos pasa; esta contradicción entre la mujer que es tu madre o tu abuela, $y$ lo que tú quieres ser $y$ no eres todavía; esta especie de frontera entre el ideal y la realidad. (I57-58)

In her recent collection of essays, "la contradicción", "el querer ser y no ser todavía have stopped signifying impotence or absence only, and allude to women's plurality, bisexuality and heterogeneity. They are presented as an androgynous alternative that looks for neutralization, union of the contraries - inside-outside, indoors-outdoors, object-subject of the gaze/writing, weak-strong, emotional- 
rational, victim-victimizer-, and all the binary oppsitions that ultimately refer to the traditional masculine-feminine dichotomy. The dichotomy system is a masculine construction and the woman writer today has liberated herself of the negative implications that come with it, because she refuses to believe in it anymore. Roig believes that women writers have taken off the imposed mask of passivity, emotion, body, reproduction, and have understood that women are not simply "nature", in the same way that men are not simply "culturen (1992:68).

In Roig's terms, women look at the world and therefore write the world with a one-eyed, double gaze (mirada bòrnia); in other words they look with the eyes of those who are excluded and included at the same time, those who stare and are also stared at. Feminine vision and discourse reveal the duality in which women live, on the one hand as members of the dominant culture, on the other as belonging to a voiceless minority group. Roig admits that it is difficult for women to create out of their own experience a new and unrecognizable voice, a different linguistic code that escapes the code imposed by patriarchal society on all its members. If there is any possibility to decodify the masculine discourse and distort it, fragment it, or express it differently, it will be through writing; yet it would be an individualistic sort of writing that strays from the prototype of woman writer proposed by certain feminists. French feminists like Annie Leclerc and Hélène Cixous wrote that the feminine linguistic subversion has to be made with the flow of blood and the first sounds of a pregnant womb. It is true that woman's voice originates from the attentive reading of her body, but as Roig points out, "no escrivim, només, amb el cos... no som solament matèriay (82). The subversion starts with the creation of a discourse that reproduces the female body and sexuality in order to deprive them of the mystery and darkness traditionally assigned to them by patriarchal thought. However, the vindication of the "essential" feminine functions and the insistence on "difference" as the only possible way to redemption, without a deep questioning of the limitations that come with it, can be problematic as it embraces the traditional masculine vision. 
In L'hora violeta Agnès loks at her pregnant womb in the mirror and like Colometa in La plaça del diamant,

hi veia un monstre, una deformitat que no sabia si s'agradava o es rebutjava. De vegades, li semblava que es delia amb la deformació, d'altres en fugia, com si mirés el cos d'un altre ésser, no una dona, sinó un monstre que li hagués pres el rostre. I pensava, tot és un engany, qui m’ha convertit en això? (29)

The immediate identification of the "feminine" with the "maternaln made by some feminists does not escape traditional notions of feminity. This identification in repudiated or denied by either feminists who see in it a way to appease man's incapacity to engender and the social anxiety it produces, but ignores the mother's subjectivity. As Doanne and Hodges argue, universalizing discourses about motherhood are prescriptive because they define feminity in relation to mothering and establish women's agency as a set of approved behaviors toward infants; besides they do very little to change fixed notions of feminine entity and subjectivity (I). To put it in their own words: "Despite the feminist impulse behind the revival of object-relations accounts of the mother-child dyad, ${ }^{3}$ the desire to elevate the mother has worked to define women narrowly as mothers, and to define mothers as the idealized and blamed origin of the child, the family and the staten (6).

In «Stabat Mater", Kristeva sees what is inside her body as the "other", who emerges not as an extension of her own body but as a stranger, as her opposite:

What relation is there between me or, more modestly, betweenmy body and this internal graft, this crease inside, which with the cutting of the umbilical cord becomes another person, innacessible? My body and... him. No relation. Nothing to do with one another. Nothing to do from the first gestures, cries, steps,

${ }^{3}$ Psychoanalytic accounts of mothering, have been profoundly influenced by the work of Melanie Klein, D. W. Winnicort, Nancy Chodorow, and Julia Kristeva. This psychoanalitic writers "understand object relations, that is, the child's relation to internalized "objects", most often the breast of the mother, as the child's first caretaker" (Doane and Hodges, I). 
well before his personality has made him my opposite: the child, he or she, is irremediable another. (III-12)

Like Kristeva, Agnès subverts the traditional discourse of motherhood as follows:

On era l'altre? Què era? El corb, el vampir, el cos inconegut que la dominava i l'esbalä̈a... La bola llefiscosa i peluda que pujava cap a la gola, era l'altre, l'altre que formava part del cos però que no era ella, que era a dintre seu però que no li pertanyia. (40)

The womb, the bedroom, the house, the patio of the family house are the primary spaces of feminine existence. In Roig's universe, female spaces are the interiors of Barcelona's houses where women dream with fictional worlds amd project themselves through patios and galleries to the city bustling in front of their eyes. Women look at themselves as well as at the world; they start looking at their inner selves to understand the outer world; they see with the eyes of their minds and of their memories. The outer spaces are many and diverse. They are the wild regions inhabited by the fictional heroines, about whom Mundeta Jover dreams in the attic of her house. The streets of Barcelona before the Civil War where Judith Fléchier lives an independent life teaching piano lessons, and Katy shocks the women of the Nuria with her daring sexual life. The same streets of Barcelona devastated by the war where Mundeta Ventura, who never leaves her house, looks for her disappeared husband under the debris. Also the streets of London where Natalia Miralpeix tries to escape the paralysis of her maternal city. And, again, Barcelona silenced but bustling with clandestine political commitment and student revolts, where Norma and Mundeta Claret, and many other women, play the role of the faithful comrades demanded by the Francoist resistance. Or the same city of Barcelona free at last but inhabited by disappointment and disaffection where Norma recovers from oblivion the horror of the deported Catalans of the Nazi concentration camps. 
Inner and outer spaces are part of the female experience; fears, indecisions and failures alternate with resolutions, initiatives and succes; pleasure and pain, frustrated desires and shared ecstasy coexist in love relationships. Moreover the subversion of the traditional roles is articulated in different ways and frequently, for the generation of the Mundetas Jover, Mundeta Ventura and Patricia Miralpeix, is never attained beyond isolation, paralysis or resignation. The ideological commitment with the women's cause is never simple or unique. Norma and Natalia, the latest generation of Roig's female characters, who have consciously rejected submission and resignation, look at their bodies and still do not know how to claim them as their own. They feel forced to pretend that they are strong and in control, and still at times they do not relate to the youngest generation's claims. Norma admits:

Tinc la sensació d'haver arribat tard. A la fotografia, al feminisme, a l'amor, Estrangera a tot arreu. Quan vaig a una assemblea de dones em sento lluny d'aquestes noies joves que tenen fe. Quan esbronquen els homes perquè no entrin a les reunions i després es piquen l'ullet entre elles. Quan surten al carrer i criden a favor de l'avortament i reclamen el dret al seu cos. (4I)

Self-consciuosness and the urge of freedom create a lot of anguish and anxiety. They can become another kind of imposition.

Roig's feminism, in her own terminology, is "double" or "oneeyed" (borni). It represents the women who wish to be strong but are unable to, who are victims and know it, who suffer man's abandonment and repeat the old role of Penelope. It represents the women who have to be Penelope to become Circe and then Calypso; and also those who after so much solitary waiting have learnt how to be independent and strong enough to reject their opressor. Above all, it represents the woman writer who, like Mercè Rodoreda, "es venja a través de la literatura" (78) without expecting to serve as model to anyone. Roig's feminism should be understood as an individual struggle that does not turn woman into a merely ideological construction. Its function should be, above all, to impel her to articulate her own voice, to express the plurality of 
her female self, because, as Natalia Miralpeix said in L'hora violeta: "Només quan t'has sabut mirar a tu mateixa, aprendràs a mirar el que et volta.... (23i).

\section{ISOLINA BALLESTEROS HARVARD UNIVERSITY}

\section{BIBLIOGRAPHY}

Bellver, Catherine G. "Montserrat Roig and the Penelope Syndromer. $A L E C$ 12.I-2 (1987): III-I2I.

-, «Montserrat Roig: A Feminine Perspective and a Journalistic Slantw. Feminine Concerns in Contemporary Spanish Fiction. Eds. Roberto C. Manteiga, Carolyn Galerstein and Kathleen McNerney. Maryland: Scripta Humanistica, 1988. 162-170.

DoAnne, Janice and Hodges, Devon. From Klein to Kristeva. Psychoanalytic Feminism and the Search for the "Good Enough" Mother. The University of Michigan Press, 1992.

FALCON O'NeILl, Lidia. "A modo de resumen del año feminista". Poder y Libertad: Revista Teórica del Partido Feminista de España 2 (r98I): 5-24.

KrISTEVA, Julia. "Stabat Mater". The Female Body in Western Culture. Ed. Susan Suleiman. Cambridge \& London: Harvard University Press, 1985. 99-119.

NicHOLS, Geraldine C. «Montserrat Roig». Escribir, espacio propio: Laforet, Matute, Moix, Tusquets, Riera y Roig por st mismas. Minneapolis: The Institute for the Study of Ideologies and Literature, 1989. 147-185.

RoIG, Montserrat. ¿Tiempo de mujer? Barcelona: Plaza y Janés, I980. -. L'hora violeta. Barcelona: Editions 62, 1980.

—. L'opera quotidiana. Barcelona: Plaza y Janés, I982.

—. Ramona, adéu. Barcelona: Plaza y Janés, 1972.

—. Els temps de les cireres. Barcelona: Plaza y Janés, 1976. 
-. Digues que m'estimes encara que sigui mentida. Sobre el plaer solitari d'escriure i el vici compartit de llegir. Barcelona: Edicions, 62, 1992.

ROMERo, Isabel; Alberdi, Isabel; MARTíneZ, Isabel y ZAUnER, Ruth. "Feminismo y Literatura: La narrativa de los años 70». Literatura y vida cotidiana. Seminario de Estudios de la Mujer. Ed. María Ángeles Durán, José Antonio Rey y Mar de Fontcuberta. Zaragoza: Servicio de Publicaciones de la Universidad Autónoma de Madrid y Secretariado de Prensa de la Universidad de Zaragoza, 337-59. 